\title{
Central Banks and The Money Supply
}

\author{
by A. JAMES MEIGS and WILLIAM WOLMAN
}

\begin{abstract}
The following paper was presented at the Second Konstanz Seminar on Monetary Theory and Monetary Policy, Konstanz, Germany, held from June 24 to 26, 1971. A. James Meigs and William Wolman are Vice Presidents in the Economics Department, First National City Bank, New York. Dr. Meigs was an economist with the Federal Reserve Bank of St. Louis from August 1953 until April 1961. Dr. Wolman was the Economics Editor and later a Senior Editor of BUSINESS WEEX prior to poining First National City Bank in 1969.
\end{abstract}

The article is presented as part of the continuing discussion of money supply control: Can central banks control the money supply? Why don't central banks control the money supply? Should central banks control the money supply? Should the world money supply be controlled? Much of this paper was drawn from the forthcoming book by A. James Meigs, MonEY Matters: Economics, Markets, Politics (New York, Harper and Row Publishers).

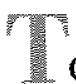
obvious than the desirability of establishing the money supply as the target variable for central bank policy. To any economist, nothing could be more obvious than the distaste of most central bankers for this course of action.

Events of the current year have, indeed, dealt a severe blow to monetarists' hopes that they have made some headway in moving public policy in their direction.

In the United States, the Federal Reserve system appears to have abandoned the pursuit of aggregative targets, or at least to have pushed them far into the background. When interest rates began to rise in February of this year because of the economic recovery that had begun in December and to soar during the international monetary crisis in May, the Federal Open Market Committee (FOMC) was hesitant about letting them rise too quickly. The FOMC Record of Policy Actions, together with certain explanations of how open-market operations are conducted that were published in the Monthly Review of the Federal Reserve Bank of New York and the Federal Reserve Bulletin, ${ }^{1}$ signaled the early stages

IPaul Meek and Rudolf Thunberg, "Monetary Aggregates and Federal Reserve OpenwMarket Operations," Monthly Review, Federal Reserve Bank of New York, Vol. 53, No. 4, April 1971 , pp $80-89$.

"Record of Policy Actions of the Federal Open Market Committee," Federal Reserve Bulletin, Vol. 57, No. 2 February 1971, pp. 105-119. of the change in policy emphasis explicitly. The behavior of the U.S. money supply this year, a growth rate of almost 12 per cent through the end of May, has signaled it statistically.2

In the world at large, the setback to the new way of thinking about monetary policy, or, rather, the reversion to more traditional modes, was less explicit, but nevertheless visible in the events and statements surrounding the monetary crisis of May 3-5. Truth surfaces in periods of strong emotion. The language used to describe the act of love - or the fact of death - is a language that goes to the heart of the matter. (In economic affairs, international currency crises are the emotional equivalent of love or death.) It is, therefore, depressing that virtually every cliche was dragged out in the wake of that crisis to espouse atavistic doctrines (international coordination of interest-rate levels) and to denounce sensible solutions (the floating of the German mark). The effect was to set back the cause of providing a rational basis for international monetary harmonization.

But monetarist setbacks in the policy disputes of 1971 may nevertheless be laying the groundwork of future gains in the wider areas of analytical debate. The ultimate test of a set of scientific ideas is their

\footnotetext{
2The Joint Economic Committee of the U.S. Congress, which had recommended in 1968 that the Federal Reserve keep the rate of growth of the money supply (narrowly defined, $\mathrm{M}_{1}$ ) within a range of 2 per cent to 6 per cent annual rate, neg. lected to renew the recommendation in 1971 . Thus was the frst official recommendation for a monetary rule withdrawn.
} 
power to predict. It is the unpleasant duty of monetarist economists to predict the consequences of the 12 per cent growth rate in the U.S. money supply if it is allowed to persist much longer: a rekindling of inflation and the threat of new international monetary crises. It is the confident, though depressing, expectation of monetary economists that these predictions will prove out because all the discriminating evidence that can be gleaned from economic history supports the validity of the monetarist hypothesis, at least at this level of generality.

Given this set of attitudes, any monetarist discussion of central bank behavior is in obvious danger of degenerating into an exercise in pathology. But the authors of this paper intend to resist this course of action as best they can. Instead, they will address themselves to four questions: (1) Can central banks control the money supply? (2) Why don't central banks control the money supply? (3) Should central banks control the money supply? (4) Ought the world money supply be controlled?

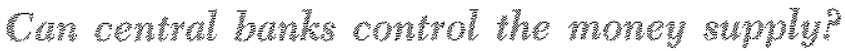

The authors of this paper have nothing new in the way of systematic empirical evidence to offer on the question of central bank control of the money supply. They nevertheless believe that a review of the building blocks that led to the establishment of the monetarist theory of the money supply process would be useful, although, of course, familiar to all the participants in this seminar.

The United States is the logical place to commence this exercise. More work has been done on the money supply process there than in other countries. It is also apparent that the role of the dollar as a reserve currency, together with the existence of a vast pool of intermational liquidity denominated in dollars, poses special problems for central banks outside the United States. The U.S. case is therefore, in effect, the closed-economy case. We will take up the implications of U.S. money-supply changes in an open world economy later.

A convenient framework for spelling out this process is the one used by Allan Meltzer in his 1959 study of the French money supply and by Milon Friedman, Anna Schwartz, and Phillip Cagan in their historical studies of the U.S. money supply."

\footnotetext{
"Allan H. Meltzer, "The Behavior of the French Money Supply: 1938-1954," Joumal of Political Economy, Vol. LXVII, June 1959, pp. 275-96. The approach used by Meltzer was developed iointly with Karl Brunner, See Albert $\mathbf{E}$. Burger, "An Analysis and Development of the Brunner-
}

At center stage is "high-powered money" - sometimes called "monetary base" - which consists of bank reserves plus currency held by the public. In the United States, bank reserves are deposits of commercial banks at Federal Reserve Banks (the monetary liabilities of the reserve banks) and currency held by the banks. Defining, issuing, and regulating the quantity of high-powered money are governmental functions shared with, or delegated to, the central bank. The ratio of the narrowly defined money supply (demand deposits and currency) to high-powered money in the United States is about 2.55 to 1 . If we use the broad definition of money preferred by Milton Friedman and others-currency, demand deposits, and time deposits in the commercial banks - the ratio is about 5 to 1 .

If the money multiplier were always the same, changes in the money stock would be determined entirely by changes in the quantity of high-powered money. A 5 per cent increase in high-powered money would produce a 5 per cent increase in the money supply. But this multiplier is not constant; the banks and the public can change it and therefore can change money supply to some degree, even if the quantity of high-powered money is fixed.

How the banks and the public use the available supply of high-powered money, therefore, determines the size of the money multiplier - the ratio of total money supply to high-powered money. Two ratios are crucial here in determining what the money multiplier is: the ratio of currency to total money that is maintained by the public and the ratio of reserves to deposits that is maintained by the banks.

Changes in three variables - the volume of highpowered money, the currency-money ratio, and the reservedeposit ratio - therefore, can account for all changes in the money supply. Money supply will be increased by an increase in high-powered money, by a reduction in the rauio of currency held by the public to total money supply, or by a reduction in the ratio of bank reserves to deposits, if the other two determinants remain fixed.

This is the accounting statement - the $C+I+G=Y$ or the $\mathrm{MV}=\mathrm{PT}$ - of the monetarist view of the money supply process. The interesting questions are

\footnotetext{
Meltzer Nonlinear Money Supply Hypothesis," Working Paper No. 7, Federal Reserve Bank of St. Louis, May 15, 1969. Also see Milton Friedman and Anna I. Schwartz, A Monetary History of the United States: I867-1960, (Princeton: Princeton University Press, 1963), see especially Appendix B pp. 776-808; Phillip Cagan, Determinants and Effects of Changes in the Stock of Money: 1875-1960, (New York: National Bureau of Economic Research, 196.5. Distributed by Columbia University Press.)
} 
empirical: why does the supply of high-powered money change, and are the two ratios sufficiently stable (predictable) so that the Federal Reserve can, in fact, control the money supply?

Phillip Cagan gave the long-term answer to the first question. Over the long period 1875-1955, he found that increases in high-powered money came from two sources - growth of the gold stock and, after the Federal Reserve system was established, growth in credit extended by the Reserve Banks. The counterparts of these in other countries would be growth of foreign exchange reserves (including gold) and growth in domestic assets of the central banks.

The Cagan data make it obvious that changes in high-powered money dominate the long-term movements of money supply. Data developed by Brunner and Meltzer established the far more controversial proposition that changes in high-powered money also dominate short-term movements in the money stock.4 They found, for example, that 85 per cent of the variation in the monthly changes in the narrowly defined money supply is accounted for by changes in the monetary base and in Treasury deposits at commercial banks in the current and previous months. Treasury deposits may be a troublesome source of static, but systems to cope with this kind of noise can be designed, and changes in the monetary base are by far the most important determinant of the money supply.

With this relationship estimated over the 200 months ending in March 1965, Karl Brumner and Allan Meltzer were able to predict monthly changes in the nonseasonally adjusted money stock for the months of July 1966 through September 1969 with impressive results. These kinds of exercises relating changes in high-powered money to changes in the total money stock are persuasive evidence that the two critical ratios do not behave in a totally erratic manner. The behavior of these ratios nevertheless merits some attention.

The public's ratio of currency to demand deposits is quite volatile. It has a pronounced cyclical pattern, rising on the eve of recessions and falling during recessions. The currency ratio, however, can be observed and predicted well enough that changes in it can be prevented from changing the total money supply. The Federal Reserve has good information

${ }^{4}$ Cagan, Determinants and Effects of Changes in the Stock of Money, pp. 18-21. The Brunner-Meltzer results are reported in Allan $\mathrm{H}$. Meltzer, "Controlling Money," Review, Federal Reserve Bank of St. Louis, May 1969, pp. 16-24. on the flows of currency into and out of the hands of the public and so can promptly offset any change in the currency ratio that threatens to produce undesired changes in the money supply.

The reserve-deposit ratio determines the total volume of bank deposits. Much of the literature on the difficulty of controlling the money supply assumes that this ratio is highly variable and unpredictable. There are two main sources of change in the reservedeposit ratios in the United States (other than changes in the reserve requirements set by the Federal Reserve Board). The first is the fact that reserve requirements differ among classes of banks and types of deposits. The second is variation in banks' demand for cash or excess reserves.

A good deal can be said about the first source of change; but most of it, while interesting, would unduly lengthen this paper. In his pioneering study, The Supply and Control of Money in the United States, Lauchlin Currie pointed out in the early Thirties that shifts within the U.S. system would cause difficulties for money supply management, if the system ever became interested in trying it. ${ }^{\overline{5}}$ In principle, he was correct. In practice, however, shifts in the average reserve-requirement ratio are surprisingly small (except, of course, the occasional changes in the whole structure that the Board of Governors may make for policy reasons). George Benston found in a recent study, for example, that changes in the distribution of demand deposits among classes of member banks and between successive reserve settlement periods are small and predictable. ${ }^{6}$ Long-term qualitative changes, however, have been produced by a steady drift of demand deposits from city banks, where reserve requirements are high, to country banks, where reserve requirements are low.

Shifts of deposits between member banks and nonmember banks are a minor source of uncertainty in predicting total demand deposits, largely because the Federal Reserve has information on nonmember deposits only at the June and December call dates. Between these dates the Fed must estimate them. As Benston and Clark Warburton have pointed out, however, the nonmember banks do not escape Federal Reserve limits on their power to expand because they are required by state banking laws to keep

\footnotetext{
${ }^{5}$ Lauchlin Currie, The Supply and Control of Money in the United States (2nd ed., rev. Cambridge: Harvard University Press, 1935), pp. 69-82.

GGeorge J. Benston, "An Analysis and Evaluation of Alternative Reserve Requirement Plans," Journal of Finance, American Finance Association, Vol. XXIV, No. 5, December 1969, pp. $849-70$
} 
reserves with larger banks, which usually are member banks.

In the short run, banks have little or no influence on average reserve-requirement ratios. Over a longer time period, however, they can influence the ratios by inducing the public to hold more time deposits in relation to demand deposits, as U.S. banks did during most of the Sixties, for instance. But such changes are so gradual that they should not cause difficulties for money-supply management. Regulation $Q$ ceilings on time-deposit rates also change the reserve ratio, as in periods of "disintermediation" or "reintermediation."

In addition to the reserves they are required to hold, U.S. banks hold some cash "excess reserves" in the form of currency in their own vaults and deposits at Federal Reserve Banks. In countries where there are no reserve requirements, banks also hold some cash. It is through this paper-thin margin of bank cash that central banks wield their greatest influence on bank decisions to buy or sell earning assets, and thus to expand or contract deposits. For the central banks are the ultimate source of bank cash, which they create or extinguish. "It is clear, or at least we must hope so," said W. F. Crick long ago, "that the banks, so long as they maintain steady ratios of cash to deposits, are merely passive agents of Bank of England policy, as far as the volume of money in the form of credit is concerned."7

Volumes have been written in attempts to refute that simple statement, most of them relying on the theoretical possibility that cash ratios are not steady. Yet, for the United States, the stability of the banks' reserve ratios is remarkable. Jerry Jordan of the Federal Reserve Bank of St. Louis has found that the ratio of total reserves (required reserves plus excess reserves) to total commercial bank deposits is the least volatile of all the ratios that determine the overall money multiplier. ${ }^{8}$

Yet this proposition continues to be met with great skepticism by those who cling to the man-in-thestreet view that business conditions - the volume of credit demands-determine the money supply. Richard Davis of the Federal Reserve Bank of New York says, " . . . the possibility of important influences

7W, F. Crick, "The Genesis of Bank Deposits," reprinted from Economica, 1927, in Readings in Monetary Theory; Friedrich A. Lutz and Lloyd W. Mints, (New York: Blakiston Co., $1951)$, p. 51 .

8Jerry L. Jordan, "Elements of Money Stock Determination," Review, Federal Reserve Bank of St. "Louis, October 1969 , pp. $10-19$. running from business to money seems to weaken substantially the evidential value of the work done by Friedman and his collaborators in trying to establish a dominant causal role for money." Generally, it is argued that increasing interest rates stimulated by an increase in business activity will induce banks to reduce their ratio of reserves to deposits and money supply. Davis, however, was unable to find much evidence that this actually happens. Nor has anyone else found such evidence.

Why is the ratio of bank cash to bank deposits stable? One answer is the quantity theory - the theory of the demand for money - in microcosm. Banks behave like the general public in that they want to hold some cash for emergencies. But bank managers keep their eyes on the risks and chances for profits that face them. They are not going to hold much more, or much less, cash than they think they need. Although an individual bank may be willing for a few days to tolerate a cash position that is lower or higher than its accustomed level in relation to total deposits, the bank will expand or contract its earning assets, and hence its deposits, if the discrepancy persists. Some U.S banks are content to remain in a cash-deficit position, that is, to be borrowing daily from other banks or the Eurodollar market. But somewhere in the banking system there must be some cash to be passed around from bank to bank. In the United States, that free cash amounts to only about $\$ 200$ million, compared with around $\$ 450$ billion of total commercial bank deposits.

It is difficult to resist some comment on discussions of the relations between money and business that have taken place in the United States over the past nine months or so. In the final quarter of last year, when the money supply grew relatively slowly, those who were skeptical of the causal role of high-powered money in the money supply process dragged out the old "you can lead a horse to water but you can't make him drink" arguments as explanation. They implied that the Federal Reserve could not increase the money supply more rapidly with business activity depressed. Those same economists continued to talk of a sluggish economy in the first six months of this year, yet the money supply grew at a 12 per cent annual rate. It would be well for those who believe that a large share of causality runs from business to money to remember that you can't have your horse and eat him too.

9Richard A. Davis, "How Much Does Money Matter? A Look at Some Recent Evidence," Monthly Review, Federal Reserve Bank of New York, Vol. 51, No. 6, June 1969, p. 124. 
We come now to the question of money-supply control outside the United States. It is obviously more difficult for other central banks to control their money supplies than it is for the Federal Reserve System. For one thing, the flows of currency across their exchanges tend to be large relative to their domestic money supplies. For another, the instrument of monetary control that has the swiftest effect on the monetary base - open-market operations - is of limited usefulness to central banks in countries with thin markets for short-term credit instruments. We will take up these points briefly, if only to serve as a focus for some of the issues under discussion at this seminar.

In many countries, surpluses or deficits in international payments balances are said to force expansion or contraction of domestic money supplies despite what the central banks may try to do. This, it is argued, makes countries vulnerable to "imported inflation" - especially inflation imported from the United States.

That there has been plenty of imported inflation since the 1958 move towards convertibility is not a proposition that the authors of this paper are inclined to dispute. As a matter of fact, we agree that excessive monetary expansion in the United States from 1964 through 1968 contributed substantially to growth of the world money supply in those years and subsequently as well. But we nevertheless raise the question of whether the degree of imported inflation that countries have tolerated was entirely out of their control.

From a monetarist point of view, the question at issue is whether inflows of foreign exchange must inevitably show up in the monetary base of the affected countries in a 1:1 ratio - or at all for that matter. In pursuit of this point, Ira $O$. Scott and Wilson Schmidt in a 1964 paper pointed out that the central banks of Europe had indeed been adding to the stock of high-powered money by buying foreign assets. ${ }^{10}$ But they also noted that central banks had been buying domestic assets in the course of their lending to their governments and others through their discount windows. Not all of the inflation was imported; some was homegrown. To prevent it, said Schmidt and Scott, the central banks should have offset their purchases of foreign exchange with sales of other assets. Paolo Baff, of the Banca d'Italia,

\footnotetext{
"थIra O. Scott, Jr., and Wilson E. Schmidt, "Imported Inflation and Monetary Policy," Ouarterly Review, Banco Nazionale del Lavoro, December 1964, pp. 390-403.
}

found that between 1959 and 1967 central banks of the larger European countries actually added to the expansionary effect of increases in foreign exchange reserves by augmenting their credit to domestic borrowers. ${ }^{11}$

This kind of analysis immediately raises the question of the relative orders of magnitude of domestic vs. foreign influences on the monetary base of countries around the world. In pursuit of an answer, much scholarly work has already been done-some of the most notable by members of the Monetary Project at this University. And the answers have generally pointed in this direction; casual empiricism has generally tended to overstate foreign influences on the size of the monetary base and to understate domestic influences. The implication, of course, is that many countries, in fact, had more room for maneuvering in pursuing stable monetary growth than they chose to see.

No attempt will be made to analyze the efficiency of instruments other than open-market operations in controlling the money supply, except to note again that much of the skepticism over their effectiveness results from examples drawn more from their misuse than from their inherent limitations. Central bank lore and practice, for example, mitigate against frequent and small changes in discount rates. Yet, if monetary control were the overriding goals of policy - and if this were made perfectly clear to market participants - frequent and small changes in discount rates might prove to be a fairly efficient method of monetary control.

In any event, a central bank bent on pursuit of a money supply target has methods available to it to beef up its capacity for directly influencing high-powered money. In his study, Central Banking in Latin America, Frank Tamagna of the American University in Washington, D. C., reported, for example, that the Banco Central de la Republica Argentina issued securities of its own that it could sell when it wanted to influence the monetary base. ${ }^{12}$ It sold certificates of participation in a portfolio of government bonds that otherwise would not have been marketable.

\footnotetext{
11Paolo Baff," "Western European Inlation and the Reserve Currencies" Ouarterly Review, Banco Nazionale del Lavoro, March 1968, pp. 3-22, Also see Manfred Willms, "Controlling Money in an Open Economy: The German Case," Review, Federal Reserve Bank of St. Louis, April 1971 . pp. $10-17$.

12Frank Tamagna, Central Banking in Latin America, (Mexico: Centro de Estudios Monetarios Latino-americanos, 1965), pp. $129-33$.
} 


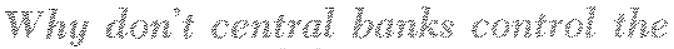

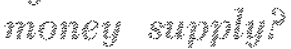

Empirical studies of relations between the monetary base and the total money supply establish a strong basis for believing that central banks can control the money supply. There are, therefore, two possible reasons why they do not. The first is that the results produced by statistical and logical analysis of past data establish a post-hoc-ergo-propter-hoc proposition - that, when a central bank actually tries to control the money supply, those relationships which theory and empirical analysis suggest are stable turn out to be operationally unstable. This, of course, means that a central bank that sets out to control the money supply would find that it cannot. The second reason why central banks do not control the money supply is simply because they don't want to.

Evidence on what occurs when a central bank actually sets out to control the money supply is extremely scarce. This fact alone vests the months since the beginning of 1970 - when the Federal Reserve made moderate growth of the monetary aggregates an explicit goal for Federal Reserve policy - with an extraordinary interest for monetarist economists.

It should be said at once that the rapid growth in the U.S. money stock in 1971, and particularly in the second quarter of 1971, raises serious question among monetarist economists about how seriously the Federal Reserve actually took the transition to the aggregative goals it announced in early 1970. Nevertheless, the behavior of the aggregates in this period merits some analysis.

The behavior of the U.S. money stock from the point when the aggregative goal was adopted to the end of the first quarter of 1971 looks quite good to the monetarist economist. It is true that the 5-6 per cent monetary targets, that the Federal Reserve said it was pursuing, appeared too high to be consistent with true price stability. But this behavior could be excused as being a transition set towards a more appropriate growth range of $2-3$ per cent for money supply.

Yet, even within this overall framework of high grades, there were specific points at which the Federal Reserve could be faulted - where operating techniques led the money managers astray. They will be discussed in ascending order of importance.

The first is the lagged reserve requirement for the member banks introduced in 1968. This rule stipulates that the amount of daily-average required reserves the banks maintain in each statement week is based not on that week's deposits but on the deposits of two weeks earlier. As a result of this rule, the Federal Reserve reacts to influence the stock of highpowered money after the banks have expanded or contracted deposits, rather than taking the initiative in supplying the extra stock of high-powered money to which the banks must adjust.

The destabilizing impact of the lagged reserve requirement was revealed by a series of sharp increases of demand deposits in certain weeks of 1970 and 1971 that showed up like blips on a radarscope. One of the worst of these was the week ending April 1, 1970, when the demand deposit component of the money supply increased by $\$ 7.5$ billion before seasonal adjustment and $\$ 6.4$ billion seasonally adjusted, which was more than the expected growth for the whole year at the moderate growth rate the system was pursuing at that time. Revision of the data later scaled the unadjusted increase to $\$ 4.0$ billion and the seasonally adjusted increase to $\$ 1.6$ billion, but by any measure this was an extraordinary increase for one week.

The initial cause of the April 1, 1970, increase of deposits was a postal strike which interrupted the normal flow of checks. With fewer checks being presented for payment, the banks saw an increase in deposits on their books. Two weeks later, when the banks had to meet the higher reserve requirements based on deposits of the April 1 week, the Federal Reserve supplied the necessary reserves through open-market operations. However, the reserves were supplied somewhat grudgingly because the jump in bank deposits was by then embarrassingly visible. The open-market operations effectively validated the deposit expansion and left the Federal Reserve with a difficult problem of gradually shrinking deposits and the money supply in order to get back on a normal growth course later.

More serious were the money market procedures that were adopted in order to control the aggregates. When finally explained in early 1971, they proved to be an uneasy compromise between the old practice of accommodating short-run changes in demands for credit and the new objective. As explained by members of the staff of the Federal Reserve Bank of New York, the aggregative target turned out to be an indirect one rather than a direct one. The Federal Open Market Committee attempted to specify at each meeting a set of money market conditions (interest rates and level of member bank borrowings) that staff estimates indicated would produce the de- 
sired expansion of the money supply. The money market conditions were then the operating target for day-to-day purchases and sales of securities.

If the FOMC was indeed ever serious in its pursuit of aggregative goals the results were obviously not always what the Committee intended. In the third and fourth quarters of 1970 , these procedures led to a short-fall for many weeks between the 5 per cent per year money supply target and actual monetary growth. With short-term interest rates falling rapidly in the fourth quarter of 1970 , staff estimates consistently over-estimated the rates of money supply growth that would occur with the money-market conditions that the Open Market Committee sought to maintain. The money supply grew less than intended, principally because the Committee at that time was fearful that short-term rates would fall too far and would increase the balance-of-payments deficit.

In the first five months of 1971 , the problem was just the opposite. When interest rates began to rise because of the economic recovery, the Committee hesitated about letting them rise. The effort to moderate the rise of rates through the purchase of government securities expanded bank reserves and the money supply. Staff estimates of the money-supply growth that would result from any given set of moneymarket conditions were likely then to have been consistently on the low side. Money supply must have grown more than the Open Market Committee intended because the Committee could hardly have meant to exceed the monetary expansion of early 1967, which was generally considered in retrospect to be a major mistake.

But flaws in techniques are only a minor reason why central banks do not control the money supply. The major explanation is that they don't want to. The reasons for central bank reluctance to control the money supply are complex and difficult to understand, involving as they do psychological and political, as well as analytical, elements. Enhanced understanding of why central banks behave the way they do will require far more work of biography and institutional analysis than has yet been done.

When it evolves, a good theory of central bank behavior is likely to use the stature, role, and function categories of sociological research. It is likely to conclude that institutions - including the job market tend to select as central bankers those with a talent for a particular kind of role playing: the appearanceand perhaps also the fact - of a taste for stability. Those individuals who rise in central banks are peo- ple who can impress other people that they can keep their heads no matter what - and no matter whether it is true or not.

Central bankers, moreover, will be shown as having exceptionally catholic tastes in choosing targets for stabilization. As historical actors, their ideal role is that of defenders of society from any institution and individual, or any set of ideas, that society perceives as threatening to impair stability, whether the threat is, in fact, credible or not.

Since the chief sphere of central bankers is obviously the financial markets, their chief stabilization targets are obviously financial variables. And since the most immediately visible signs of financial change are prices of financial assets, central bankers tend especially to be fascinated with controlling interest rates and exchange rates to present an aura of stability in financial markets.

It is, of course, a platitude to say that financial stability is desirable. It is also true that the processes that select stability maximizers as central bankers are historically useful. The real question, of course, is over the rules of central bank behavior that are most likely to produce that stability.

One aspect of central bank taste for stability manifests itself in a desire to stabilize everything at the same time. A fascinating manifestation of this tendency has been central bank reaction to the rise first of Keynesian analysis and then of monetarist analysis.

Keynesian analysis of the policy transmission mechanism placed great stress on the role of investment spending in influencing the level of economic activity. Policy influenced investment via interest rates. Accordingly, the requirements of policy could be large changes in interest rates - particularly in light of the Keynesian view that private investment is inherently unstable. Irrespective of the merits of the Keynesian case, it obviously posed a major challenge to central bankers, with whom interest rate changes are about as popular as hoof and mouth disease. The reaction in the United States was the development of the credit availability doctrine. Economists of the U.S. Federal Reserve System, led by Robert V. Roosa, developed this new theory of monetary control soon after World War II. ${ }^{13}$

\footnotetext{
13Robert V. Roosa, "Interest Rates and the Central Bank," in Money, Trade and Economic Growth, prepared in honor of John H. Williams (New York: Macmillan, 1951), pp. 270295. See also Ira O. Scott, Jr., "The Availability Doctrine: Theoretical Underpinnings," Review of Economic Studies, October 1957, pp. 41-48.
} 
Belief in the efficacy of credit availability had two main roots: a centuries-old concern of central banks over the amounts and kinds of credit and the famous surveys of the $1940 \mathrm{~s}$ that showed that interest rates had little effect on investment spending.

The credit-availability doctrine purported to triumph over the apparent disability of interest rates by maintaining that monetary policy works much more through influencing the availability of credit than through influencing the cost. Therefore, it held that it is possible to curb spending through restricting the availability of bank reserves without raising interest rates very much (and vice versa). It was easy to see why the new theory should be eagerly seized as the rationale for Federal Reserve policy, for, as James Tobin has said, "it offered the hope that monetary policies can be effective without the large fuctuations in interest rates which used to be considered essential."14

The Federal Reserve has yet to come up with a formal theoretical umbrella for monetarism. But in the specific rules for guiding behavior that emerged after the adoption of an aggregative target in early 1970, the central bank desire to control everything again manifests itself. We have already discussed these procedures. We only note here that the motivation for adopting them is related to a desire to control interest rates and money-market conditions as well as the money supply itself. This is probably the reason that the control procedures that emerged were in fact a hybrid aimed, as Jerry L. Jordan and Neil A. Stevens of the Federal Reserve Bank of St. Louis have pointed out, at trying to control "money-market conditions on a day-to-day basis with a view to controlling money-market aggregates over the longer term." 15 According to this approach, the growth of the demand deposit component of the money stock can be influenced by interest rates as well as the so-called transactions needs of the public, and money market pressures can be controlled in such a way as to achieve a desired growth of deposits. The difficulties with the rules of behavior that spring from this hybrid theory have already been described.

This brief discussion of the Federal Reserve response to theoretical challenges hardly points to all the morals in the story of Federal Reserve resistance

${ }^{14}$ James Tobin, "A New Theory of Credit Control: The Availability Thesis," The Review of Economics and Statistice, Vol. 35, No. 2, May 1953, pp. 118-27.

15Jerry L. Jordan and Neil A. Stevens, "The Year 1970-A "Modest' Beginning for Monetary Aggregates," Review, Federal Reserve Bank of St. Louis, May 1971, p. 18. to controlling the money supply. But it does show a strong Federal Reserve preference for controlling or seeming to control - many variables rather than just one.

Even if the central bank chooses to control only one variable, it is unlikely that the money supply would be the optimal choice dictated by institutional considerations. Controlling the money supply would mean that the Federal Reserve would have to allow interest rates or money-market conditions to vary (although it is our belief that the amount of fluctuation that would occur can easily be overestimated). And this variation would occur in the precise areas where the Fed most prefers stability. This preference stems from a traditional central bank concern with the state of markets - particularly the market for government debt - and from a tendency to infer what would make for stability in the economy from what is perceived as making for stability at that point in the economy that is the proximate matrix of Federal Reserve actions - again the market for government debt.

It is finally worth noting that questions over the motivation of the actions of a central bank are similar to those in other parts of a government bureaucracy. Adopting a money supply standard or any other measurable standard for action is one that people instinctively resist, preferring instead leeway for $a d$ hoc justifications of past behavior.

\section{Onght Centud Banks control the money stupply?}

Because monetary policies affect the economy with long time lags, the monetary authorities cannot immediately see the effects of their actions on such key variables as national income, employment, and prices. Therefore, they must use intermediate guides for their day-to-day operations to tell them if they are exerting an influence in the right direction and in appropriate amounts.

The current world debate over the proximate goals for guiding monetary policy focuses on two main possible guides or groups of guides. On the one side are interest rates, which are price measures. On the other side are the monetary aggregates. We have already seen that central banks strive for a compromise between the two, but both guides cannot be followed at the same time. If a central bank attempts to control interest rates, it must allow money supply to fluctuate. If it controls money supply, it must allow interest rates to fluctuate. 
A good guide must have two characteristics. First, it should be closely under the control of the central bank so that the central bank can interpret a change in the guide as the result of its own actions rather than the result of outside forces. Second, changes in the guide should have a strong and predictable relationship to changes in ultimate policy variables, such as income, employment, and the price level. The grand theme of the monetarist challenge is that the money supply fits these criteria better than any of the available alternatives. We will not here attempt an elaboration of this grand theme but only a minor variation on it.

Insofar as a case for monetarism exists in the minds of noneconomists, it is because of the pursuit of interest rate targets by the Federal Reserve in the second half of the 1960s. The record of the FOMC (always properly interpreted) indicates that three major attempts were made to keep or push interest rates lower than they would otherwise have been in the short run: in late 1965 and 1967 and again in 1968 . In each instance, the money supply spurted and interest rates behaved in accordance with monetarist predictions. Policy makers were each time eventually confronted with a material escalation in the rate structure that could hardly have been said to be a goal of policy. Each time, moreover, the economy also behaved in accordance with monetarist forecasts even though in 1968 fiscal policy was highly restrictive. The two episodes of restrictive monetary policy in 1966 and 1969 also produced economic behavior much in line with the expectations of monetarists.

The existence of some kind of a case for monetarism in the mind of the public is perhaps not without relevance to the evolution of central bank policy, for it may in the end make a poor Boswell out of Harry Johnson. In the Ely lecture at last December's meeting of the American Economic Association, Johnson argued that monetarism is on the way out because, as the economics of inflation, it would be abandoned by governments who perceive that the public prefers full employment to price stability. ${ }^{16}$ We, by contrast, would prefer to view monetarism as an analytical position. And in the realm of policy we would be quite content (in the present state of knowledge) modestly to define monetarist policy as one in which the monetary authority pursues stable growth of the monetary aggregates.

\footnotetext{
10It is impossible within the space available to treat adequately the reasoning by which Harry Johnson reaches this conclusion. See Harry G. Johnson, "The Keynesian Revolution and the Monetarist Counter-Revolution" The Richard T. Ely Lecture, The American Economic Review, May 1971, pp. 1-14.
}

Based on what the Federal Reserve has done so tar in 1971, Professor Johnson does indeed look like a good Boswell. But the market reaction to Federal Reserve policy this year makes the fate of his prediction less certain. Interest rates have risen on signals that the rate of growth of the money supply was increasing. It is difficult for the Federal Reserve to overlook this reaction. And if market participants become convinced monetarists (as they might, given sufficient conditioning), the rise in long rates would be just sufficient to build the appropriate Fisher premium into long-term interest rates.

Insofar as the level of interest rates influences spending decisions, it is expectations of the real rate that count. This is a point on which good monetarists and good Keynesians both agree. Accordingly, the ascription of potency to movements in the nominal rate depends on the public being fooled in the short run. But if the public becomes monetaristminded this won't happen. Accordingly, any possible domestic argument for central bank pursuit of interest rate targets would fall to the ground. Johnson may well be right about the preferences of policymakers. But if we are right about the behavior of markets, his conclusion could nevertheless turn out to be incorrect, for it could turn central bankers into pursuers of aggregative targets.

This argument also applies to the character of the short-run tradeoff between the rate of employment and the rate of inflation. Insofar as more inflation buys less unemployment, it is because participants in labor markets are fooled into perceiving changes in the nominal values of wages as changes in real values. But again, public perception of the impact of rapid monetary acceleration would greatly reduce the short-run employment bang that the Federal Reserve buys for a buck.

Public perception, public policy, and economic analysis do interact. This minor theme reinforces the major theme of monetarist analysis that central banks ought to pursue the goal of stable monetary growth. Indeed, the minor theme represents one possible basis - there are others - for believing that Harry Johnson could have been wrong about the ultimate fate of monetarism.

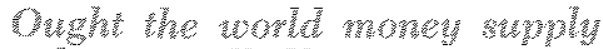

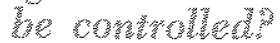

When a definitive history of monetarism comes to be written, it will probably characterize the intellectual process by which the monetarist position on in- 
ternational monetary affairs came to be almost solely identified with flexible exchange rates as unfortunate. Flexible rates are obviously a key to a rational system of international monetary coordination. But even more so is the monetarist emphasis on stable monetary growth rates. Moreover, the kind of monetarist analysis that has made headway in the United States through pointing out the irrationality of the conventional targets of macroeconomic policy has an equal bearing on the conventional wisdom about the proper scope and content of rules for the international coordination of economic policy. It is unfortunate that this emphasis is only now coming to the attention of policy makers and the public.

It is a dogma among economists that most of the world's ills spring from the malfeasance, misfeasance, or nonfeasance of politicians. But comfortable as this view may be, it can be argued equally cogently that much of the trouble with the world monetary system today springs directly from the tendency of politicians to do what economists tell them to do.

If world monetary equilibrium can be roughly defined as reasonably stable exchange rates, reasonably full employment, and reasonable stability of world prices, it would describe a state that clearly does not exist in 1971. Everywhere prices are rising. Some exchange rates have been jumping, while others have been held at parity only by large central bank operations in foreign exchange markets. Therefore, countries have neither stable prices nor stable exchange rates. And economists have to bear a good share of the responsibility for this state of affairs.

Any short statement about the sources of the current malaise is an oversimplification. But it is perhaps not totally unrealistic to attribute most of the disturbance to the excessive money-supply growth in the United States between 1964 and 1968. Although the United States was by no means responsible for all of the world's price inflation, there is no question that the burst of U.S. money supply growth between 1964 and 1968 accelerated it. Nor are the hands of economists entirely clean in any analysis of why this occurred. It is true that the weight of U.S. economic opinion did favor a tax surcharge to pay for the Vietnam war - and favored it before it was recommended by the Administration and long before it was enacted into law. But many economists argued for low interest rates in late 1965 . The weight of economic opinion favored the rapid reversal of monetary policy in the 1967 minirecession. Furthermore, the pessimistic forecast that led to a burst of money-supply growth in 1968 , when the tax surcharge was enacted in the
United States, was widely shared in the economics profession.

It is also true that insofar as the Federal Reserve has again turned to rapid monetary expansion in 1971, its actions are supported by the analysis of those economists who persist in ignoring the direct effect of money supply growth on income and prices and who continue to identify a stimulative monetary policy with the deliberate pursuit by the central banks of low nominal interest rates.

Clearly then, one requirement for movement toward a better world money system is better economic analysis. And, as in the case of domestic policy, monetarism clearly has an important role to play. Again, a full adumbration of the monetarist view of world money is beyond the scope of this paper. Instead we will content ourselves with the statement of a number of maxims. The first series will be prohibitions, a series of statements of what not to do if world monetary coordination is to be achieved. We will then state two positive rules that we believe would promote world monetary equilibrium.

The most important of the negative rules is one for the U.S. Federal Reserve: If the Federal Reserve is to contribute to world monetary equilibrium, it will have to give up its attempts at contracyclical policies at home or in the world as a whole. As our discussion of Federal Reserve actions has already indicated, much of the monetary acceleration of the years from 1964 to 1968 was the result of attempted contracyclical actions. Coping with bad forecasts and with the lags between policy actions and their effects in the U.S. economy is difficult enough. When the additional transmission lags of international payments are considered, it should be obvious that managing world contracyclical policies from Washington and New York exceeds the capacities of the Fed - or of any other agencies for that matter. The Federal Reserve cannot be the world's central bank, nor is one needed.

Given the tendency of economists to tinker and prescribe, this is a difficult anti-maxim to follow. When money supply growth in the United States accelerates, the U.S. balance-of-payments deficit increases and the world money supply grows more rapidly, This has suggested to some economists, including Robert Mundell of the University of Chicago and Richard Cooper of Yale, that the Federal Reserve System should try to stabilize the world economy by supplying more money at some times than at others. Mundell, for example, said in 1968 that the Federal Reserve has completed a full cycle of tight money 
and easy money during 1966-67 that was consistent with the requirements of the world economy. ${ }^{17}$ That was far too generous an appraisal, for the volatile U.S. monetary policies of those years had markedly increased economic instability and price inflation not only in the United States but in the rest of the world.

The idea of steady growth in the U.S. money supply should appeal to the reluctant partners of the United States in the international monetary system, although it runs counter to a deepseated central banker aversion to being constrained by rules. Gyrations in U.S. policies, which other countries have seen as balance-of-payments problems, have been deeply unsettling to them in recent years, and with good reason. If they must live with the dollar - and there does not appear to be a ready altemative if they want fixed rates, too, - other countries should prefer a predictable, stable dollar to one that incessantly bounces to the latest beat in the U.S. economy.

A corollary of this rule, of course, is that other countries too should avoid contracyclical policies. It is worth noting that the conventional analysis which ascribed the most recent monetary crisis to a difference in cycle phases between countries was correct. But most commentaries failed to point out that the cycles at issue can hardly be described as resulting from the inherent instability of any private economy. Instead, they were cycles caused by the character of contracyclical policies in the Unted States. Essentially, they were reverberations of the initial distur* bance caused by the hyper-expansive U.S. policies of 1964-68. Nothing could do more to mitigate business cycles than the abandonment of contracyclical monetary policies around the world.

All attempts at international interest-rate coordination should be abandoned, as should the attempts to affect the term structure of rates. Those officials and economists who have called on the United States to raise interest rates to affect the flow of funds across the exchanges have asked U.S. authorities to do the impossible. Are higher interest rates to be achieved by a deceleration of monetary growth? If so, the policy would be self defeating in the long run, which might not be a very long run either, given the tendency of U.S. capital markets to behave increasingly as monetarists say they should. Or are higher rates to be achieved by an acceleration of monetary growth? This policy might achieve the expected results; but surely it is not what Europeans, who would have to

\footnotetext{
17Robert Mundell, "Toward a Better International Monetary System," Journal of Money, Credit and Banking. Vol. I, No. 3 , August 1969 , pp. $630-31$.
}

cope with another wave of dollars, have in mind. A desire to manipulate interest rates is deepseated among those who worry about balance-of-payments equilibrium. Its antecedents reach all the way back to the early Mercantilists. But it is to be doubted that interest-rate manipulation can make even shortrun contributions to stability, particularly given the enhanced tendency of markets to act on monetarist expectations.

The so"called international liquidity problem should be recognized for what it is -essentially a side issue. Much attention has been focused on the seeming paradox of worldwide concern about a shortage of international liquidity at the same time a worldwide price inflation indicates that the world is actually swamped in money. It is understandable that central bankers worry that there may not be enough of the kinds of money that they prefer for their own use. Dollars have become less attractive to some central banks, as shrinking U.S. gold holdings make it obvious that the United States cannot convert all centralbank dollars to gold.

Central bankers also do face a dilemma of what to use for reserves if the United States were ever to succeed in eliminating its balance-of-payments deficit. But the provision of a reserve asset is not the most important problem in the evolution of the international monetary system. Fears that domestic deflation might result from a deficiency in international reserves seem greatly exaggerated. A shortage of international reserves may make it difficult to avoid changes in exchange rates, but it would not force domestic deflation on a country that did not want to deflate. Central bankers are surely ingenious enough to find domestic assets they could monetize in a pinch, whatever the state of their international reserves. If anything, they are likely to err on the side of doing too much rather than too little.

Nor, in view of the pressure to exchange real goods and services, is there a serious danger that the growth of intemational trade and investment will be strangled by a deficiency in the supply of official reserves. The traders of the world will find the monetary instruments necessary to do their work, unless, of course, govermments block their way with controls, Right now, dollars serve the needs of trade very well. To rephrase an old slogan: money follows trade; trade doesn't follow money.

Controls are not the way to deal with the so-called Eurodollar problem. The Eurodollar market at its present size is a function of controls, including U.S. 
balance-of-payments policies, such as the interest equalization tax and the "voluntary" restraint on bank loans to foreigners and the mandatory restraints on direct foreign investment. All of these controls could and should be abandoned. If they were, and if the regulation of bank time-deposit rates in the United States were abolished, the Eurodollar market would wither to a shadow of its former self. It would not be a great offshore, out-of-control creator of dollars. Removal of controls - not another layer of controls - is the way to deal with the Eurodollar problem.

If these particular anti-maxims add up to one grand anti-maxim, it is this: the goal of world monetary equilibrium should not be pursued directly. In the Aristotelian view, he who pursues happiness directly will find it elusive. Happiness, instead, is an unsought reward for doing other things well. So it is with economic policy.

The positive monetarist maxim for international equilibrium is for central banks of the world to concentrate on doing what they can do-controlling money supply - and to abandon attempts to do what they cannot do-controlling interest rates and balance-of-payments deficits or surpluses. By following a steady-growth policy, furthermore, they would have the best chance of enjoying both price stability and stable exchange rates.

If the world stays with the fixed-exchange-rate system, with the dollar as the key reserve currency, the system would resemble the gold standard but with steady gold (dollar) production. The world money supply would be determined primarily by the United States. The steady rate of dollar production, however, would enormously simplify the world's monetary problems.

The rate of dollar inflow is a determinant of moneysupply growth in surplus countries; but, as we have seen, it is not - and certainly need not be - the sole determinant. Central bank purchases of domestic assets (or loans through their discount windows) usually are even more important than their purchases of foreign exchange as sources of highpowered money, This is obviously true also of the deficit countries because they have no net dollar inflows to force money-supply expansion. Controlling their purchases or sates of domestic assets, therefore, will permit central banks to control domestic money supply in a fixed-exchangerate system, if exchange parities are reasonably close to equilibrium levels and if no major country upsets the system by expanding its money supply too fast.
To initiate such a system, however, may require adjustments to today's parities.

If a particular country lets its money supply grow slightly too fast (in relation to the rate of growth of the supply of dollars), it will lose dollars from its reserves. This suggests a way by which central banks can get rid of the dollars they accumulated in pegging rates after the U.S. inflation began in 1965 . If a country lets its money supply grow at less than the equilibrium rate (with relation to the dollar), it will gain reserves. In either case, little harm would be done either to exchange-rate stability or to price stability if the money-supply growth rates are stable.

One of the principal advantages of the steadygrowth rule from the standpoint of the international monetary system is that it would greatly reduce pressures to change exchange rates. The question of whether to have fixed rates or free rates, therefore, would become less important because exchange-rate stability could be maintained under either system. Volatility of national monetary policies has overwhelmed attempts to achieve exchange-rate stability under the fixed-exchange-rate system in the past.

Exchange rates would be more stable if they were allowed to float in a world in which individual nations followed steady-growth monetary policies than they would be with a system of adjustable pegs. This is because there would not be the incentive for destabilizing speculation that the one-way options of the peg system provide now. The small residual adjustments in exchange rates that might be necessary if central banks follow a steady-money-growth rule should occur slowly and gradually enough that businessmen could allow for them as they now allow for changes in the purchasing power of domestic currencies.

Another advantage of the steady-growth rule (especially with floating rates) is that elaborate arrangements for international coordination of policies would not be required. If agreement on policies is sought, it is far easier to agree on something simple that can be carried out entirely at home by each country.

By floating their exchange rates, furthermore, those countries that agreed to follow steady, noninflationary monetary policies would be protected from disruptions caused by countries that were not willing to go along. The world would then have sound money and stable exchange rates within the group of steadygrowth countries and unstable rates between these countries and the outsiders. The advantages of free 
trade and investment should provide incentive for more countries to join.

In such a world, the countries that did not bring money under control would soon learn the lesson pointed to by Sir Dennis Robertson in 1948:

Now if a country is rapidly increasing its supply of money, the same lack of confidence in the future of the money which ultimately worms its way into the skull of the thickest-headed citizen, strikes like a ffash upon the consciousness of the well-informed and impressionable gentlemen whose business it is to carry on dealings in foreign money. They become highly willing to buy foreign money and to sell the money of their own country. ${ }^{18}$

18D. H. Robertson, Money, Cambridge Economic Handbooks II (London: Pitman Publishing Corporation), pp. 119-20.

This article is available as Reprint No. 69 